\title{
LOS DRAMAS DE LA CONCIENCIA Y LA MEMORIA
}

\author{
José Paulino Ayuso \\ Universidad Complutense de Madrid
}

\section{RESUMEN}

Entre el teatro político y el teatro histórico debe haber un lugar para el de la memoria, que trata de la realidad pasada en función de su sentido para el presente de la sociedad, según Paul Ricoeur. Dentro de esta modalidad, en la trayectoria del franquismo, hubo una memoria impuesta de los vencedores y una memoria, ficcional e incluso imaginaria, de los vencidos. Con Buero comienza una reflexión inmediata acerca de la memoria herida y del olvido como enfermedad. El artículo sigue la línea de la reflexión más que la mera referencia a hechos y acontecimientos. Así, ya desde la democracia, se vuelve a la función restauradora de la memoria colectiva de los vencidos y al debate acerca de la memoria misma y la amnesia, como cuestión simbólica no resuelta, de la que se refieren varios ejemplos.

Palabras clave: teatro, memoria, Buero, franquismo, democracia.

\section{ABSTRACT}

In the 'theatre of the memory', during the Franco's regime, there was an imposed memory of the victors, and also a memory, fictional and even imaginary, of the defeated ones. Buero begins a reflection on the wounded memory and on the oblivion as a disease. In the democracy, there appears again the topic of the collective memory of the losing ones and the debate on the memory itself and on the amnesia, as a symbolic not resolved question.

Key Words: theatre, memory, Buero, Franco's regime, democracy.

\section{INTRODUCCIÓN}

Puesto que las memorias del franquismo pueden ser abordadas desde diversas perspectivas, deseo anticipar que las páginas que siguen responden a una doble 
elección. Seleccionan obras dramáticas, en un recorrido relativamente amplio, desde el final de la guerra civil hasta la actualidad, para dirigirse a un apartado, de obras recientes, que establece el debate y que pretende ser el centro de interés para mostrar que, de diversas maneras, la cuestión se plantea y sigue abierta. Por otra parte, dejo de lado la atención particular a hechos concretos referidos y a personas evocadas, es decir, los detalles de la historia, con ánimo de fijarme en la función de la memoria misma y en las formas dramáticas en que ésta se presenta. Y para plantear esta cuestión he tomado como guía un pequeño tratado de Paul Ricoeur, seleccionando de él lo más pertinente, sin entrar en especulaciones: La lectura del tiempo pasado: memoria y olvido (1998). Precisamente, la primera cuestión abordada es la que sirve de marco a las consideraciones y aplicaciones del resto de este trabajo, pues plantea la posibilidad de hablar lícitamente de una «memoria colectiva».

Ricoeur parte de la constatación de la supuesta primacía de la memoria individual, la única, al parecer, que puede ser considerada. Le corresponden tres rasgos: es radicalmente singular y constituye por sí sola un criterio de la identidad personal; es el vínculo original de la conciencia con el pasado («la memoria es el presente del pasado»); y a ella corresponde la orientación del sujeto a lo largo del tiempo. A continuación, recurre a los estudios del sociólogo Halbwachs para establecer la necesidad de introducir también el concepto de «memoria colectiva». Y, de nuevo, resume unos hechos de evidencia fenomenológica: el primero y más importante, «que uno no recuerda solo, sino con ayuda de los recuerdos de otro», por lo que añade que «nuestros recuerdos se encuentran inscritos en relatos colectivos, que, a su vez, son reforzados mediante celebraciones y conmemoraciones» (Ricoeur, 1998:17). De esta proyección de la memoria en la vida pública tomamos una parte de nuestros recuerdos, pero, sobre todo, de ella tomamos el marco necesario para darles lugar, primero, y sentido, después. Porque la memoria individual parecerá significativa en tanto se inserte en el ámbito y como parte de una conciencia de memoria colectiva, que es propia de la comunidad histórica. Con todo, sigue discutiendo la legitimidad de ampliar la noción de memoria a un sujeto colectivo, para concluir que se trata de una transferencia analógica, de modo que «la memoria colectiva sólo consiste en el conjunto de las huellas dejadas por los acontecimientos que han afectado al curso de la historia de los grupos implicados que tienen la capacidad de poner en escena esos recuerdos comunes» (Ricoeur, 1998:19). Aunque obviamente el autor no piensa en el teatro, sino en los ritos y celebraciones públicas (de los que el franquismo tanto se sirvió para la fijación de su memoria), aquí se verifica de modo literal la «puesta en escena» y la «representación», dado el carácter público y colectivo del hecho teatral. 
El conjunto de fenómenos analizados y explicados «sugiere, más bien, la idea de una constitución simultánea, mutua y convergente de ambas memorias» (Ricoeur, 1998:19). Tal vez el argumento decisivo venga de considerar que los recuerdos se articulan y llegan a luz -con mayor o menor resistencia- por el lenguaje, que es, en principio, común y social, público y compartido. Y los términos y conceptos empleados son aquellos que están en uso y circulación. Más aún, la expresión lingüística de aquellos se forja también con imágenes (no siempre verdaderas) y adopta una forma de relato. Aquí hemos encontrado un punto de apoyo definitivo para la reflexión acerca de la memoria evocada, transmitida y reformada a través del teatro. Aunque mejor decir de esas memorias, que forman una parte integradas en la memoria colectiva. El propio Halbwachs definía así la relación de la memoria individual y la colectiva: «son los individuos los que recuerdan, en tanto miembros de un grupo [...] Puede decirse que cada memoria individual representa un punto de vista sobre la memoria colectiva y que ese punto de vista cambia según el lugar que ocupo en ella y que ese lugar cambia a su vez según las relaciones que mantengo con otros medios» (Jaisson, 2008:101). Y en su primera etapa establece que el marco social para la memoria es el lenguaje.

Voy a plantear la exposición siguiente sobre esta relación entre la memoria individual y la colectiva, teniendo en cuenta otras nociones y considerando, además, que la relación entre ambas se establece lingüísticamente en el modo del relato, sea puramente ficticio (que lo será respecto del argumento inventado) o esté compuesto con materiales históricos reconocidos. Ahora bien, no siempre es fácil ni feliz la atención a las imágenes y hechos del pasado. Aquí se impone lo que Ricoeur, siguiendo a Freud, denomina el trabajo de la memoria. Ya somos conscientes de hasta qué grado existen resistencias sociales para aceptar o esclarecer el pasado en determinadas circunstancias o para recuperar los restos, como marcas o señales que testimonian también la verdad de ese pasado en tanto nos afecta e interpela.

Por tanto, creo que conviene establecer también de antemano dos pares de conceptos previos. Me refiero aquí a memoria colectiva con las características propias antes señaladas, en referencia a una comunidad humana, y no a memoria histórica, ya que esta equivaldría a la noción misma de historia, con sus aportaciones de hechos documentos y su exigencia de veracidad. La historia tiene que ver -dice Ricoeur- con la verdad, mientras que la memoria se refiere a la fidelidad, pues la historia trata de los acontecimientos y la memoria del sentido, es decir, respectivamente del pasado en cuanto pasado o del pasado en cuanto evocación del presente que se encamina hacia el porvenir. El otro par de conceptos es el más obvio (pero útil para nosotros) de memoria y olvido. Si he dicho que hay siempre un trabajo de la memoria, es decir, esfuerzo marcado por necesidades 
de la identidad personal y por exigencias éticas, es precisamente porque existe el olvido, que tiene, a su vez, una doble dimensión: sea para evitar reconocerse (hacia atrás) en ciertas actuaciones, sea por necesidad de seguir viviendo hacia adelante, es decir, un olvido «terapéutico». En cualquier caso, el olvido mantiene una relación con la otra cara de la identidad.

El olvido puede abrir un espacio para la vida, pero los hechos y su influencia no quedarán cancelados mientras no sean objeto de recuperación por la conciencia, movida por un impulso ético. ${ }^{1}$ Este es el núcleo de la reflexión dramática de Buero Vallejo, según mostraré, que indica fenómenos de oclusión del recuerdo que aparecen en la superficie de los hechos como casualidades, señales del pasado, vueltas y repeticiones. Aquí podría plantearse la cuestión de la deuda y del perdón, pero no seguiré ese camino. Lo que parece, a la luz de estas nociones, es que las memorias del franquismo tienden a presentarlo como aún no pasado, proyectándose en el presente y ocupándolo, dando pie a actos repetitivos, de carácter más bien dialéctico, con silencios o tomas de postura enfrentadas, que, sin embargo, reproducen (en un plano simbólico) los enfrentamientos originarios y muestran que no se han curado, sino reprimido, y por ello se manifiestan como memoria traumática. La cuestión, que tampoco puedo responder, es si la ficción del teatro ayuda a recuperar y sanar esa memoria. Así parece deducirse de algunos intentos, aquí referidos, de Sanchis Sinisterra y de Alonso de Santos, mientras otros abogan por no cancelar los hechos luctuosos con el olvido que sepulta sin duelo, como es el caso de López Mozo.

Así he vuelto sobre la cuestión de la relación entre la memoria colectiva y el teatro. La memoria, que atrae al presente los recuerdos, que son del pasado, más que una recuperación produce la ficción de una representación. A la memoria se le asocia la imagen, y, en ocasiones, la imaginación puede cambiar o sustituir la realidad vivida. En cualquier caso, para elaborar esas imágenes con sentido para el presente es necesario el lenguaje; por ello no se trata aquí de hablar de la marca o la huella (de los hechos) sino del testimonio (sigo a Ricoeur de nuevo). Según lo que he dicho antes, la recreación de la memoria no tiene necesariamente que atender tanto a la veracidad de los hechos (aunque alguna se exigirá) como a la recreación y a la crítica, conjuntamente, en relación con el sentido que concedemos a nuestro pasado y con el modo como nos situamos en la dialéctica de recuerdo y olvido. Por ello, la representación no necesita ser real, sino verosímil. Los dramas de los personajes individuales (reconocibles o no) encarnan los fe-

1. Escribe Ricoeur: «La amnistía que no es pronunciada por una instancia judicial, sino política, resulta más discutible, en la medida en que equivale a una amnesia institucional que nos invita a hacer como si el acontecimiento no hubiese sucedido» (Ricoeur, 1998: 63).

Anales, 21, 2009, pp. 11-38 
nómenos de la realidad social, porque «necesitamos el relato empírico [historia] y el de ficción para poder llevar al lenguaje nuestra situación histórica» (Ricoeur, 1999:153). Pues, en definitiva, de eso se trata, ya que la memoria, repitámoslo, está en función del presente y de un presente no sólo individual, sino colectivo, abierto y no concluso.

Cierro esta introducción con otra de las sentencias de Ricoeur, que sirve para dar paso al estudio: «No debemos olvidar, por tanto, y también y quizá sobre todo, para continuar honrando a las víctimas de la violencia histórica» (Ricoeur, 1998: 40). De todo esto se trata aquí, de presentar y analizar las distintas formas que adoptan las memorias dramáticas del franquismo, a partir de la constatación de su necesidad y de los conflictos mismos de la memoria.

\section{MEMORIAS DE LA VICTORIA Y DE LA EXCLUSIÓN}

Quiero anticipar que no abordaré el teatro histórico, el considerado como tal. Hay abundante información, estudios y bibliografía sobre el tema (véase Romera Castillo y Gutiérrez Carbajo, 1999). Solamente inicio este recorrido con dos perspectivas, a partir de la ruptura provocada por la guerra civil y el exilio, y por tanto, con la proyección sobre dos memorias, en que se articulan dramáticamente los recuerdos de cada parte. Tampoco pretendo, de ningún modo, revisar exhaustivamente los casos. Más bien proponer algunos modelos.

1.- La instauración de una memoria restauradora

El final de la guerra civil dejó los escenarios en manos de los vencedores. Es natural que aparecieran en ellos dramas sobre la contienda. Estas propuestas sólo podían dirigirse a los espectadores convencidos. Y, aunque aparecen voluntaristas manifestaciones de altura dramática y cuidado en la fijación de personajes y caracteres, con frecuencia se recurre al melodrama, lleno de proclamas ideológicas que sustituyen a los rasgos psicológicos, o, a la inversa, en que se atribuyen a defectos de la voluntad (el odio, la revancha) lo que fue la reivindicación social o el planteamiento histórico de la lucha de clases. Los valores nacionales-tradicionalistas reviven en obras de comienzos de los años cincuenta. La pretensión de instaurar un orden nuevo, resultado de la lucha, lleva a la visión exclusivamente negativa del pasado inmediato. Así, cabe entender, desde nuestra perspectiva, que estas obras promueven la creación de una memoria para el futuro, tal vez no estrictamente en los primeros años, pero sí a medida que lo requieren el desgaste del tiempo y las carencias de la autarquía. Entonces había que renovar la memoria del hecho originario y marcar un antes y un después, con retóricas llamadas a la comprensión y al perdón. Me refiero a dramas 
como El cóndor sin alas (1951), de Juan Ignacio Luca de Tena, y a El estupendo Juan Pérez (1952), de Ángel Zúñiga. Este último contiene buenas dosis de crítica social sobre los grupos aristocráticos, carentes de espíritu e inconscientes del significado profundo de lo que ocurría en los años treinta, algo que había hecho, a su modo, José María Pemán en Almoneda (1937). El desenlace, con la boda de Laly, aristócrata, y Juan, obrero, apunta a la creación de esa nueva sociedad que sale de la guerra.

Al comienzo era necesario también mirar atrás para asentar los valores de esta sociedad en una memoria recobrada. Si, por una parte, la retórica oficial hablaba de la instauración de un orden nuevo, por otra se mostraba, a la vez, como restauración de un tiempo también fundacional, con una idea política, el de Isabel la Católica, Cisneros, la conquista de América, etc. Ahí están algunas obras de la primera década y, por entonces también, las de José M. ${ }^{a}$ Pemán, como La Santa Virreina (1940), que prolonga de alguna manera su visión imperial y católica de El divino impaciente (1933).

Baste la mención para proponer la función de ese teatro militante desde la perspectiva de nuestro trabajo. Cualquier explicación más en este sentido llevaría a lugares conocidos y frecuentados. Pero parece necesaria la referencia porque establece de forma ejemplar la dialéctica de la memoria colectiva entre el pasado y el futuro, por su significado para el presente. Lo fundamental en su caso es precisamente reconocer el fundamento: la guerra necesaria. Desde ella se instaura una memoria de la victoria para siempre, cuyo núcleo es una supuesta memoria restauradora, la del Imperio.

\section{2.- Exclusión y Memoria}

Este apartado presenta dos vertientes complementarias. Se plantea, por un lado, la existencia de obras que pretenden ofrecer algún tipo de representación de la memoria, con situaciones y hechos ficticios y no vividos y experimentados por el autor. Y, por otro lado, atiende a obras que tratan de introducir la memoria de los otros, expatriados, que nunca quisieron dejar de ser del lugar propio, y cuya historia se pretende recuperar. Tanto en un caso como en otro podemos decir que son también memorias del franquismo, precisamente como memoria colectiva de la exclusión. La pregunta de cómo recordar lo que no se ha conocido o vivido exige volver un momento sobre la distinción entre los recuerdos (individuales) y la memoria (colectiva), en el sentido establecido por Halbwachs y Ricoeur. No se pueden tener recuerdos sin experiencia propia, pero sí memoria.

Tal memoria inventada o fantaseada no aporta datos verídicos, aunque puede recogerlos de informaciones solventes. Y con esos elementos es capaz de recrear un universo de relaciones, marcar pautas de conducta personal o social 
que corresponden a una época. Por tanto, no se refiere a los hechos particulares sino al sentido general. En este lugar se ofrece, sobre todo, la extensa obra de Max Aub, escrita en México. Sus novelas de la guerra civil parten de hechos conocidos y padecidos por el autor; no así sus dramas posteriores, reunidos en las series «En la España de Franco»y «La vueltas». Así escribe el autor al presentar «Las vueltas»:

Que yo sepa, no he estado en España desde el primero de febrero de 1939. Las obras -o la obra- que siguen, escritas en 1947, 1960 y 1964, suceden allí, y, más o menos, en esas fechas. Inútil decir que reflejan la realidad tal como me la figuré. ¿Qué tienen que ver con la verdad? Daría cualquier cosa por saberlo, por eso las publico (Aub, 1968: 939).

He aquí la cuestión imposible de la verdad, es decir, de la relación con la historia efectiva. Pero en el plano literario, las acciones son verosímiles: el regreso de una mujer, prisionera política, a su casa para encontrar una nueva situación familiar y social; el regreso de otro preso político, condenado a una muerte civil por adversarios y amigos, que han interiorizado la represión, unos años más tarde; y la vuelta más original, porque es la de un exiliado a España, que termina nuevamente expulsado. La ficción, en este caso último, se establece irónicamente de esta manera: «Nada de lo que sigue es invención. Me lo refirió -con puntos y comas- mi hermano. Se negó a escribirlo... Evidentemente, esta versión no es teatro, como él tuvo, en cierto momento, intención de que lo fuera; pero se parece bastante a la verdad» (Aub, 1968: 971).

La relación entre esta situación ficticia y los recuerdos verdaderos estampados en La gallina ciega, la semejanza de los personajes del diálogo teatral y de estas memorias, nos invitan a reconocer que también la ficción puede formar parte de la memoria colectiva (según la afirmación de Paul Ricoeur) si pertenece con autenticidad al marco histórico y social en que se sitúa. Y todavía puede recoger con mayor agudeza (y moderado apasionamiento subjetivo) la trama de los acontecimientos, si no la menuda enumeración de estos, acompañada por las abundantes referencias culturales y las menciones de autores con nombre supuesto o con sus propios nombres, tanto del exilio como de España.

Hay en el diálogo de Max Aub una idea principal que se puede decir de dos maneras: una, según el personaje protagonista: «Pavese tenía razón: lo terrible no es el exilio - el confino- sino volver», a lo que replica su amiga Mariana: «El hombre se va y no vuelve. Para volver habría que ser el mismo» (Aub, 1968: 986). Así que no hay retorno, como dice de otra manera el filósofo Adolfo Sánchez Vázquez en su título: «Fin del exilio y exilio sin fin». No se trata tanto de un fenómeno de destierro o ausencia del lugar, como de destiempo. El exiliado que regresa lo hace a un sitio físico que puede ser conocido, pero difícilmente 
reconocido, porque es otro el ámbito social, vital y moral, que ya no le pertenece. Y así, tampoco puede encontrarse de nuevo con el que fue. Su identidad se le aparece rota. Entonces, está condenado a vivir la tensión entre el presente y el pasado de su memoria y a ser ajeno a la memoria de los otros.

Este es el problema que plantean las obras que he mencionado. Establecen así la perspectiva de la memoria ajena o del otro en relación con la sociedad española actual. Constatamos que el exilio político, cultural, literario de 1939 pertenece a la historia, es uno de los efectos de la victoria militar y del régimen político fundado en ella. Así está ya tratado por la historia, reconocido en lo sustancial, aunque siempre haya lagunas y carencias, como en otros aspectos. Pero lo que está incorporado a la historia no pertenece aún a la memoria, porque el exilio no parece formar parte (como fenómeno general y colectivo, poseedor de su propia memoria) del legado de su cultura para los españoles. La exclusión política y territorial ha devenido exclusión de la memoria. Y por ello, la segunda expulsión del personaje Mi Hermano, en la obra referida de Max Aub, más que una acusación política, alcanza el valor de símbolo de una realidad compleja: no hay un lugar, ni físico ni mental, para la representación de ese pasado/presente del exilio. Sin embargo, las memorias múltiples del franquismo no pueden quedar completas si no se percibe la dimensión del hueco, si no se hace presente la ausencia.

De esta conciencia del vacío de la memoria y de la necesidad de colmarlo parten algunas dramatizaciones de exiliados, como Las Republicanas, de Teresa Gracia, sobre la vida en los campos de concentración franceses, y, especialmente Morir del todo, de Paco Ignacio Taibo, escrita para la exposición de 1983 sobre el exilio en México, con la intención de establecer un espacio de conocimiento necesario en la España democrática. Esta «Crónica representable», como la subtitula, refiere la vida de los «refugiados», mediante una retrospectiva de recuerdos, no siempre personales del autor, aunque muy próximos, relacionados con las formas de conducta cotidiana. Es una crónica sentimental, pero también documental, precisa, con referencias cronológicas y locales, que se remite a un ejercicio de memoria en primera persona: relato dramatizado, en su primera parte, del curso de los años, de 1939 a 1970; mientras el segundo acto está dedicado a más evocaciones y nostalgias de lo que allí se creó, para terminar con un recuerdo a los poetas muertos del Panteón Español de México, a través de sus poemas, con un mensaje fundamental: «no les dejemos morir del todo», pues el olvido es la muerte definitiva. Para evitarlo se recurre justamente a la palabra, como relato vinculante del presente al pasado.

El planteamiento dramático de este problema, desde la misma actualidad española, y con semejante mensaje final, corresponde a López Mozo en El olvido 
está lleno de memoria (2003). Uno de sus aspectos fundamentales es la memoria crítica, planteada a partir de un debate dramático que aquí es solamente implícito, pues depende de las actitudes de los tres personajes, que resultan representativas: Edmundo es un actor que ha vuelto de su exilio en América, después de una larga carrera, y quiere alcanzar un puesto y un reconocimiento que considera merecidos; Julia es una joven periodista, que, en principio, desconoce por completo quién es ese personaje al que va a entrevistar, pero que se muestra cada vez más interesada, a medida que él recuerda; Alvar es un empresario que quiere aprovechar la experiencia del actor, pero, al tiempo, ignorar y ocultar su pasado, que considera ajeno al presente. «Por lo que sea, pasó tu hora... ¿Quién desea escuchar un revoltijo de calamidades y de fanfarrias inventadas? Llegas tarde». Porque, inmediatamente antes, le ha dicho: «No haberte ido» (López Mozo, 2003: 169).

Así, a través de las relaciones de estos tres personajes, con sus características sociales y psicológicas suficientemente trazadas, cada uno convencido de sus propias razones, aunque no siempre sean explícitos sus motivos, se establece como problema dramático ese «regreso imposible», no sólo por los cambios históricos objetivos, después de la dictadura y de la transición, sino por el olvido, que parecía ser, más que una consecuencia, una consigna de ese presente. El cambio de España comporta olvidar su pasado y, por ello, se plantea como una cuestión de discontinuidad. Frente a esto, la noble actitud de Julia pugna por saber y mostrar escribiendo. De nuevo, aparece la función conservadora y articuladora del lenguaje para la memoria colectiva. El actor exclama: «Callar... es matar los recuerdos». Por ello no quiere callar, y en una escena metateatral, que confunde al público de una representación de Calderón con el real, presente en el teatro, el actor, ya no Clotaldo sino Edmundo Barbero, reconoce y recrimina: «No se esfuercen por recordarlo. No lo han visto. Y de lo que no se ha visto no hay memoria. Es como si no hubiera existido». Para añadir: «Yo no soy nadie aquí. ¡Nadie! El público está... ciego y sordo. Eso lo resume todo» (López Mozo, 2003:178). La relación entre memoria, reconocimiento público e identidad personal queda, pues, establecida de manera explícita. Y, con su final, corrobora la relación contraria de exilio, olvido y muerte también planteada por Taibo.

La muerte en escena de Edmundo, agotado y despechado, parece el definitivo silencio sobre la memoria. Pero precisamente ésta lucha a muerte contra la muerte, por lo que Julia se dirige entonces al público, mostrando las fotos de la vida anterior del actor, en la serie de sus personajes, y les conmina: «Recuerden que tuvieron el privilegio de verle actuar en el papel más difícil, el suyo» (López Mozo, 2003:178). Con la historia de este actor (su nombre corresponde a una 
persona real cuya biografía recorre los hitos del teatro español de la República y el exilio), López Mozo se sitúa frente a las dificultades de la vuelta, anticipadas (y luego experimentadas) por Max Aub, dificultades cuya causa no es sólo vital, sino también social: la decisión colectiva de no recordar, esa «amnistía» como amnesia, frente a la que propone la necesidad y la obligación de la memoria. De esto volveré a hablar más tarde. Baste concluir reconociendo que la memoria de la que se trata aquí es justamente la memoria de la ausencia y que recordar no es sólo completar la propia identidad social, sino hacer justicia.

\section{LA MEMORIA HERIDA: BUERO VALLEJO}

Dedico este apartado a comentar unos dramas del autor en el franquismo y la transición, en que aparecen ejemplarmente los tiempos y los trabajos de la memoria. En efecto, después de los dramas históricos, que dejo de lado también, Buero propone en la década de los setenta y comienzo de los ochenta una serie de dramas de la mala conciencia social, cuyo rasgo común es el olvido culpable, más o menos voluntario, y la vuelta vindicativa de la memoria, en relación con los conductas individuales durante el régimen de Franco. Aunque, en verdad, son veinte años los que hay que atender (1967-1986), a través de cuatro obras representativas.

La primera es El tragaluz, ya que en ella se encuentra un doble proceso de recuperación de la memoria en busca de los orígenes de un mal que, en apariencia individual, resulta social. Deben investigar los personajes hacia su propio pasado, en busca del momento que determinó la situación familiar y la enajenación del padre. Esta es la tarea necesaria que no se quiere afrontar, y que se centra no tanto en el hecho, sino en cómo se cuenta tal hecho originario, que coincide con el final de la guerra y se arrastra hasta el momento presente de la historia familiar. Por otra parte, en la representación del drama, los espectadores asisten a un espectáculo que es la concreción, en forma de imágenes proyectadas, del supuesto pasado, es decir, y aunque de forma fragmentaria y discontinua, en escenas sueltas, es posible reconstruir la historia sucesiva en términos con los que confrontar el presente del público mismo, recuperando como una memoria desconocida (en la ficción) lo que es, sin embargo, el presente real del público. He aquí el doble proceso: confrontación de los personajes con su verdadero pasado y del espectador con su presente como pasado ficticio.

Paul Ricoeur emplea la imagen del archipiélago como conjunto de recuerdos, separados unos de otros, y la memoria como la acción (voluntaria) de navegar por ellos, recorriéndolos. Me parece natural y propia la aplicación a este caso, dada la forma de presentación fragmentaria de las islas de acción dramática, que se rescatan e iluminan entre mares de vacío y oscuridad. Ese recorrido hacia atrás 
es doloroso y terrible para los personajes, porque se trata de alcanzar un fondo, la terra ignota de un recuerdo clausurado o enmascarado bajo un relato, idéntico en los hechos, pero invertido respecto a su sentido: ¿Qué ocurrió cuando Vicente subió al tren, dejando a la familia, y no bajó?

Buero busca en esa obra los orígenes en un pasado reciente y todavía vivo (se acababan de celebrar los «25 años de paz»), que responde a la pregunta de dónde venimos históricamente, como sociedad que surge de una guerra. El debate entre Mario y Vicente se entiende como el debate entre memoria y olvido. Y las ráfagas de voces que relacionan el presente de ambos con su pasado infantil es otro modo de activación de ese archipiélago de los recuerdos. El olvido impone la prosperidad del presente económico, que encuentra en sí mismo su justificación y es el fundamento necesario de Vicente, mientras que sigue actuando como un mal que esconde su causa, como enfermedad en la alienación del Padre, y se convierte en otro mecanismo negador del recuerdo. Así, la situación dramática, con su dualismo de espacios escénicos y caracteres, muestra que el presente está enfermo de pasado. La curación, ya que no hay cambio, resultará traumática también. Pero de la tragedia representada se puede desprender un resultado positivo: la terapéutica de la memoria para el espectador, enfrentado a sus propios recuerdos o a los recuerdos sociales. Por ello es la sociedad la que puede reconocerse y recuperar cierta forma de memoria, que es, gracias a la representación dramática, su memoria colectiva.

A comienzos de los años setenta, la guerra, con sus crímenes y consecuencias, se presenta levemente enmascarada en Llegada de los dioses. Allí hay una situación idílica, protagonizada por un maduro pintor que recibe la visita de su hijo ciego. En verdad fue un combatiente y torturador, y para él se impone la necesidad del olvido. No recordar es ser otro, pues el fundamento de la identidad es el recuerdo. «Olvida [la guerra] hijo mío, y esperemos que nunca vuelva. Yo ya no soy aquel». En cambio el hijo, desde su ceguera, provocada según parece como reacción por la conducta criminal del padre, descubierta de súbito, dice: «Nunca ha terminado... la guerra no te ha abandonado» (Buero, 1994:1373). La imagen del espectro del torturado asciende desde el subsuelo como aparición del pasado/pasado, que regresa para vengarse en el presente, aunque sólo lo percibe la conciencia alucinada del hijo, que evoca así el recuerdo y confronta a su padre con la justicia de la memoria.

La primera parte del drama conduce hacia la ruptura de la oclusión del pasado y la recuperación del recuerdo. A partir de entonces comienza el esfuerzo del padre para conciliar ese pasado con las convenciones actuales: «ya nadie puede remediar lo que hizo...»; «los hubo más crueles...» (Buero, 1994:1377) son las frases del recurso a la justificación. Y, como en la obra anterior, también 
aquí el éxito y la feliz prosperidad se ofrecen como justificación en sí mismos para ocultar un origen criminal. Los recuerdos son fantasmas que inicialmente perturban solamente la conciencia del hijo. Sin embargo, no son propiamente suyos, sino inducidos y derivados de la historia de otro, del hijo de la víctima. Esos recuerdos parecen no afectar al padre, pero son, con metáfora de la obra, una bomba oculta bajo su suelo vital. Cuando Felipe dice: «lo peor ya se lo tragó el pasado» está a punto de sonar el teléfono para comunicar la explosión de esa bomba que mata a Nuria, la hija. Es otra vez la imagen del resto oculto del pasado, capaz de aniquilar la felicidad del presente y la esperanza del futuro. El pasado criminal no ha pasado realmente, mientras no se descubra y sane. Si no, es un destino de muerte. Al fin, para todos llegará una evidencia: «Nos acecha en el aire y bajo el suelo... Sí, la guerra sigue viva». Y Julio reconoce: «Nunca sabré por qué la ceguera. Sólo sé al fin que no soy un dios, sino un enfermo de tu mundo enfermo» (Buero, 1994: 1407). De nuevo Buero recurre a la metáfora de la enfermedad individual como producto social. Es la enfermedad del olvido de la historia, tal como la muestra esta «fábula» que, en apariencia, habla de otra sociedad, pero en realidad se refiere a la España del tardofranquismo, en que el desarrollo económico se ha consolidado.

Buero establece repetidamente esta relación entre ocultación o falseamiento de la verdad en la memoria y la enfermedad. El trauma (individual o social) tiene que ver con la ruptura entre el pasado y el presente; es entonces cuando aparecen los fantasmas de la conciencia, y sólo una acción investigadora que venza esas resistencias y establezca la verdad dará posibilidades de vida auténtica al presente. Y en esta dialéctica se insertan las dos obras siguientes. En primer lugar, Jueces en la noche. Estrenada en 1979, el franquismo resulta ahora ya un pasado, pero todavía en realidad presente, con restos como los atentados y las amenazas de un golpe militar. El personaje principal ha sido importante figura del Régimen, como ministro, involucrado también en los aparatos económicos y financieros. En el origen de su matrimonio y de su fortuna está cierta conducta criminal, que quiere ocultar y olvidar y, por tanto, en su presente aparentemente feliz, en el que se ha transformado en demócrata, se enmascara (con el recurso escénico de las caretas) la infelicidad, el desamor y la desgracia. La enfermedad se llama ahora depresión y afecta a su mujer, una de las víctimas inocentes. Estamos ante la obra más concreta en cuanto al tratamiento del fenómeno de la corrupción moral de franquismo, con numerosas alusiones inmediatas.

La cuestión de la conducta y su responsabilidad se plantea, de este modo, en el orden social y en el orden moral: «¿Habrá que recordar u olvidar según os conviene?» (Buero, 1994:1687). En el aspecto personal, la consideración de 
Juan Luis respecto de la enfermedad de su esposa ante la amiga psiquiatra es: «a tu juicio, yo soy el culpable de su enfermedad» (Buero, 1994:1683). La labor de esa amiga, respecto de Julia, es ayudarle a recuperar la verdad del pasado, oculta bajo una historia que disfrazó su verdadero sentido con un relato engañoso de la detención de su primer novio, Fermín, y de su cobardía. Verdaderamente, Julia no puede olvidar porque nunca logró entender y creer que ese pasado hubiera sido el que se dice que fue: «Tina, pienso demasiado en aquello, como si acabara de suceder» (Buero, 1994: 1663). Y ello determina una especie de repetición compulsiva de vuelta a los mismos lugares (los del origen de la historia). Se puede apreciar la habilidad de Buero para plantear, de modo diferente, una situación psicológica y social semejante a la de El tragaluz.

En el presente de Juan Luis coinciden dos tendencias opuestas. La vuelta impensada del pasado, en la figura de Ginés, antiguo inspector, ahora activista mercenario, y compinche de su engaño primero; y la oferta de su padrino político de un puesto en una importante empresa, con grandes remuneraciones. Son las dos caras de su realidad, contradictorias pero ambas propias y relacionadas. Y así, con la claridad que ahora se permite, Buero habla de una historia criminal de dos cabos, tan enlazados que forman una sola: individual y colectiva. Y aquella representa a ésta.

Pero las víctimas, olvidadas, no han desaparecido, y desde su presente no existencia dialogan con el culpable:

JUAN LUIS.- Hace muchos años de aquella ejecución... ${ }^{2}$ Otros tiempos. ¡Y yo era un niño en nuestra guerra!

CHELO.- Nosotros no hemos venido para recordarla. Es usted quien la ha recordado.

VIOLÍN.- Creemos, como tú, que hay que dejarla atrás.

D. JORGE.- Pero no pretenda que los años posteriores se borren igualmente.

VIOLíN. - A esos años sí hay que juzgarlos. Y a quienes en ellos se hicieron hombres (Buero, 1994: 1687).

El texto distingue: «los años y los hombres», es decir, las circunstancias históricas y la acción individual de los que se sumaron a la victoria en una sociedad quebrada:

Hicieseis lo que hicieseis, vosotros o vuestros padres, erais los ángeles; los vencidos, o sus hijos, los demonios. El dolor de un pueblo sacrificado; la agonía de las familias divididas, la sangre de los muertos y asesinados en los dos bandos, la inmensa pena de la España desgarrada... ridículamente degradada (Buero, 1994: 1705).

2. No se menciona cuál sea, ni tiene por qué corresponder a ninguna condena real, pero puede pensarse en la ejecución de Julián Grimau, por ejemplo, en 1963, que es una fecha plausible. 
El olvido, por tanto, es imposible y la ocultación del pasado le hace pervivir como enfermedad social (de la que la individual es metonimia). Ya no se trata de la guerra, según propone el texto anterior, sino de la larga perduración del régimen de Franco, por lo que, frente a la afirmación más propia de la transición como «dejar atrás», en esta obra se reclama la necesidad de un juicio ético que explique la condición moral del presente. La memoria del franquismo, sin embargo, no iba a ser públicamente explorada todavía más que de esta manera teatralmente simbólica, en que las víctimas se constituyen en jueces con autoridad, pero sin poder efectivo, bajo la forma de un trío de música clásica.

Las fantasmagorías mentales de los personajes en estos dramas de Buero tienen una versión menos intensa en la obra Lázaro en su laberinto (1986), aunque no menos traumática. El símbolo es aquí bastante explícito. Si los «jueces» eran las víctimas no reconocidas de la historia, que se levantan desde la conciencia de Juan Luis, el «laberinto» representa el proceso mismo de esa conciencia que busca establecer su verdad personal a partir del recuerdo, imposible sin embargo, porque aparece duplicado, como una encrucijada o un juego de espejos. La doble historia de una sola verdad: fue Lázaro valiente y salió en defensa de su novia, atacada por ultras, o fue cobarde y contempló paralizado la agresión. Nadie puede resolverle la duda, y menos al saber que ella no se marchó fuera, sino que murió, posiblemente como resultado de las lesiones. Ha estado esperando una llamada que le estableciera la verdad en su memoria, pero ya nunca se producirá.

La sociedad española ha avanzado en el tiempo. Buero da cuenta también de ello. La guerra es ya el pasado para estos personajes, ni siquiera habla del tiempo más duro del franquismo, sino de la salida de él y de los conflictos por la resistencia del llamado entonces «bunker». Pero lo que le interesa es el conflicto mismo de la conciencia y el necesario esfuerzo de la memoria. De nuevo la enfermedad mental se materializa en un signo sensible, el sonido del teléfono que sólo Lázaro oye. El pasado no resuelto sigue ocupando el espacio del presente, en forma de alucinación o de proyección: Amparo se le presenta con rasgos semejantes a Silvia, su novia perdida, sin que se llegue a desvelar si el parecido es real o inducido. Pero eso no importa tanto. Todo es muestra de la inutilidad del olvido: «Es una vieja historia... ¿vieja? Después de los días que pasé en cama noté que había perdido mucha memoria». «Pero lo sigues recordando» (Buero, 1994:1911).

Lázaro, al explicar que recuerda la historia de dos maneras distintas, añade: «Me engaño a mí mismo, pero no sé cuál es el engaño... Dirás que estoy enfermo y tendrás razón» (Buero, 1994:1914). Ya sabemos que esa enfermedad es social, pero se plantea ahora la necesidad de afrontar la verdad de las conduc- 
tas personales. Antes éstas pretendían justificarse falsamente con la situación social y se mostraban presas de su propio devenir. Ahora esa coartada ya no le es posible al personaje. ${ }^{3}$ Conocer la verdad sería el principio de su curación, como se le dice: «sólo tú puedes encontrarla». Pero el daño está en el origen y la conclusión es a la vez abierta y pesimista: «Entonces, quizás nunca sabré» (Buero, 1994:1946). Esto se representa escénicamente (aunque dudo de su valor dramático) en el debate de las dos máscaras de su recuerdo, que no llegan a ningún resultado.

La proyección del caso emblemático de Lázaro sobre la sociedad, representada por los espectadores presentes, se propone en la acotación final: comienzan a sonar timbres de teléfono por varios lugares de la sala, de manera envolvente. Su sonido es la llamada de la conciencia a la memoria colectiva. Y si algo queda claro en el proceso de la obra es que en el fondo de estos comportamientos está el miedo. Podemos deducir o suponer que este sentimiento fue provocado por la política represiva y marcó tantas vidas (Buero, 1994:1949). Entonces, la sombra del pasado (no su luz) nunca abandonará a quien no puede determinar qué fue la verdad y qué no lo fue. En consecuencia, no puede reconocerla, reconocerse a sí mismo y, tal vez, perdonarse... El olvido sigue siendo la enfermedad, porque el pasado nunca termina de ser presente.

En esta serie de obras, Buero ha mostrado el proceso de la memoria herida que deviene herida de la memoria en la vida de sus personajes y de la sociedad. Plantea con claridad sus trampas y la necesidad de un juicio ético, que parece sólo puede venir desde fuera. Ni Vicente, ni Felipe ni Juan Luis están en condición de reconocer su pasado y, en consecuencia, de renunciar a su presente. Su explicación apela simplemente a las circunstancias de modo relativo o comparativo; su justificación es la riqueza y bienestar creados; su defensa, la lejanía del tiempo y la discontinuidad o cambio personal. En los dramas de Buero ninguna de estas fórmulas vale. Sólo es necesario recordar para reconocer y sanar. Pero Lázaro muestra que la memoria estaba todavía presa de su laberinto.

\section{LAS MEMORIAS REVIVIDAS Y LAS MEMORIAS DEBATIDAS}

En la transición a la democracia, la recuperación de una parte olvidada de la memoria, la de los vencidos, recibió atención especial por dos acontecimientos teatrales, que han seguido repitiéndose: los estrenos de Las bicicletas son para el

3. Otro caso es el de la hermana, que por interés y egoísmo ha estado ocultando la realidad a su hermano. La idea de la complicidad pasiva y culpable aparece aquí de modo semejante a La doble historia del Dr. Valmy y otros.

Anales, 21, 2009, pp. 11-38 
verano (1982), de Fernando Fernán Gómez, y de ¡Ay, Carmela! (1987), de Sanchis Sinisterra, ambas llevadas al cine con éxito. Las diferencias son notables, sin embargo. Mientras la obra de Fernán Gómez era una reconstrucción nostálgica, veraz, como crónica personal de la guerra en una familia republicana, y, por tanto, un ejercicio de la memoria, el drama de Sanchis Sinisterra, en las circunstancias de la guerra -y del combate mismo-, buscaba seguir una investigación sobre el teatro, sus límites y su magia, como ha recordado el autor y recoge Aznar Soler en su edición (1998). Pero hay en ella imágenes probablemente imborrables, como la de Carmela con la bandera y el canto, en remedo degradado pero valiente de la alegoría de la República. No voy a volver sobre estas obras, por conocidas y citadas, como tampoco a otros ejemplos de drama histórico, que incluyen los casos parciales de El camarada oscuro, de Alfonso Sastre, y de Historia de unos cuantos, de Rodríguez Méndez. En todas ellas, como dice este último autor (2002), se presenta la visión de los perdedores de la guerra y, más allá, de la historia. Todos son dramas de estética realista, que ofrecen datos y elementos de la realidad social que conduce hasta el franquismo.

Para centrar el nuevo recorrido me refiero a obras más recientes y me fijo en ellas para establecer dos pares que muestran cierta relación en cada uno de ellos. En el primero, se recrean de modo ficcional situaciones propias del franquismo para dar cuenta de las condiciones de la vida y mostrar la fractura producida por la guerra civil. El tratamiento dramático, sin embargo, me parece suficientemente distinto del mero drama histórico, aunque diferente en cada caso. Y de esa diferencia habrá que inferir alguna consecuencia. En el segundo par se crean las situaciones dramáticas adecuadas para establecer un cierto debate histórico, centrado precisamente en la cuestión de la memoria, y, por tanto, en las relaciones del pasado con el presente. Tanto una como la otra posibilidad me parece que responden a la misma necesidad y exigencia, que se expresa en las palabras antes citadas de Ricoeur: "No debemos olvidar, también y quizás sobre todo, para continuar honrando a las víctimas de la violencia histórica. En este sentido, puede decirse que la memoria se encuentra amenazada» (1998: 40). Esto valdría también para los dramas de Buero, como muestra Jueces en la noche, pero no fue entonces el centro de su interés.

Hablo primero de la ficción teatral como recuerdo verdadero. Y se trata, sobre todo, de un recuerdo que se forma con datos de la propia experiencia y con otros testimonios de familiares, de conocidos, de historias que aparecen en la prensa y que terminan por fundirse para formar cierta visión personal de la memoria colectiva, con una perspectiva propia (como apuntaba Halbwachs) y, en este caso, reflexiva. Los dramas de Sanchis Sinisterra y de Alonso de Santos, que ahora considero, recogen elementos de la tradición para actualizarlos. No 
se trata de la historia, que se da por supuesta, sino del modo como fue vivida y sufrida, es decir, de la memoria. ${ }^{4}$

Coinciden ambos autores en referirse a hechos conocidos para explicar la fundación de un sistema político y social sobre la violencia. La violencia como origen y razón de legitimidad histórica, que se proyecta en una permanente fractura moral, con la división de vencedores y vencidos. Corresponde a la posición simétricamente opuesta a la memoria impuesta por los vencedores. Como no es un ejercicio de historia, no se trata de analizar o discutir, sino de no dejar en el olvido, primeramente, que el hecho originario fue la sublevación militar y la guerra, pues lo más difícil, en este aspecto, es «contar de otra manera los acontecimientos fundadores de nuestra propia identidad colectiva, principalmente nacional» (Ricoeur, 1998: 48).

El elemento central del interés por estos hechos y de la perspectiva con que se presentan es también un debate, a partir de una toma de postura implícita. Desde una democracia consolidada y no discutida, tampoco puede echarse en olvido el propio pasado, que nos pertenece aunque ya no sea directamente nuestro (no pertenezcamos a él), y que viene marcado por unas señas de identidad externas específicas, totalizadoras y excluyentes. Es Sanchis Sinisterra quien ha puesto de manifiesto, en sus notas, tituladas «Una propuesta del autor», la relación entre el presente y el pasado de esta manera:

El teatro, que siempre quiere hablar a sus contemporáneos, se vuelve a menudo hacia el pasado para nutrir el presente, para dotarlo de raíces, de sentido, de densidad [...] En vez de usar el pretencioso término de teatro histórico, prefiero hablar de teatro de la memoria (2003: 187).

Y, poco más adelante, concreta la intención: «El teatro de la memoria es uno de esos rincones en los que pretende conjurar el olvido, revisitar el pasado para entender un poco más el presente y quizás para ayudarnos a escoger un futuro... o incluso a luchar por él» (2003:188).

Terror y miseria del primer franquismo responde a estas premisas de su autor, incluso en el tiempo de su escritura. Parte de una necesidad de recordar para hacer justicia, según corresponde al comienzo de la transición (1979); y sigue por una necesidad posterior de no olvidar (que no es lo mismo) que brota de los años finales del siglo (1999-2002) con su prosperidad. ${ }^{5}$ Este «panorama de la

4. Sanchis Sinisterra ha explicado esta dimensión de la memoria colectiva: «Y aunque mi padre, profesor de Física y Química, fue represaliado y encarcelado, no tengo recuerdos concretos de aquellos años sombríos. Por tanto, he debido fabricarme una memoria que alienta en estas escenas». Y añade sus fuentes: parientes, amigos, profesores... y, «sobre todo, leyendo, leyendo mucho: libros, revistas, documentos, cartas...» (2003:189), que son las fuentes y los archivos de esa memoria.

5. «Un gran sector de la sociedad española, en estos años de la (larga) marcha hacia la democracia, adopta ante los oscuros cuarenta una actitud, sin duda comprensible, de afanoso olvido...» (Sanchis,

Anales, 21, 2009, pp. 11-38 
España de posguerra en su más anónima cotidianidad» supone el hecho originario y lo prolonga sobre distintos momentos, en una secuencia discontinua de diez años, que abarca distintos grupos sociales.

El núcleo -casi nunca explicitado- podría estar en esta secuencia de diálogo entre dos mujeres, parientes, que estuvieron en distinto bando:

MARGA.- ... como antes.

CARMINA.- No

MARGA.- No, ¿qué?

CARMINA.- Como antes, no. Nada es como antes.

MARGA.- ¿Por qué no?

CARMINA. - Ha habido una guerra, Marga. ¿Lo recuerdas?

MARGA.- La guerra acabó hace tres años, Carmina. La guerra acabó.

Ahora vivimos en paz otra vez. ¿No puedes olvidar?

CARMINA.- Puedo olvidar, sí. Espero poder. Pero nada es como antes.

(Sanchis, 2003:114).

Carmina ha perdido a su esposo, probablemente exiliado, y está acogida a la casa de Marga. Y aquí aparece esa doble posibilidad del olvido, el fácil e interesado, que quiere dejar atrás el hecho, y el terapéutico, que tiene que esforzarse para seguir viviendo. Cada uno corresponde a un bando. En cualquier caso, la nueva sociedad, que fue una restauración del modelo antiguo, se establece sobre la violencia y la división, y mantendrá una forma de memoria conmemorativa propia en actos, ritos civiles y religiosos, fechas y solemnidades. Ante ella, el mismo olvido terapéutico resulta difícil. ${ }^{6}$

La perspectiva desde la que se presentan estas nueve escenas está marcada por el título, calco de otro de Bertolt Brecht, que comporta connotaciones morales insertas en las referencias históricas de sometimiento y exclusión de los vencidos. De este modo, las escenas de Sanchis Sinisterra, que recorren desde la huida por la derrota, con la destrucción personal que acarrea, hasta la situación emergente de nuevos grupos político-religiosos y la consolidación de la nueva casta de triunfadores, se plantean como la necesaria construcción de una memoria colectiva, de un esfuerzo ético contra el olvido, memoria concreta y viva, referida a situaciones familiares y cotidianas, a veces con cierto amargo humor («Por el amperio hacia Dios»).

Decantada claramente hacia la ficción se presenta La cena de los generales, de José Luis Alonso de Santos, basada en una supuesta cena de Franco con los jefes

2003: 31. Texto inédito de 1980). Y completa esto después: «Veinte años más tarde, ante el alarmante giro a la derecha de la sociedad española y la -en mi opinión- reaparición de síntomas neofranquistas en la clase política, me propuse reanudar y concluir el antiguo proyecto, impulsado por los mismos propósitos: ofrecer a la memoria un cobijo digno y compartible» (Sanchis, 2003:189).

6. «Abolir el pasado - el contenido de la memoria- o maquillarlo ha sido siempre, y muy especialmente en el siglo XX, un objetivo prioritario de los totalitarismos» (Ricoeur, 1998:187). 
de sus ejércitos, en los salones del hotel Palace, poco después de la ocupación de Madrid. La falta de cocineros, encarcelados por «rojos», sitúa al teniente encargado de los preparativos ante un problema que sólo se resuelve sacándolos temporalmente de la cárcel. La situación, sin embargo, se hace difícil porque los camareros forman sin excepción con los vencedores, algunos de forma militante en la Falange. Por debajo de las incidencias de la preparación y los enfrentamientos verbales y gestuales entre ambos grupos, se desarrolla la trama de una boda clandestina entre dos miembros de la cocina, que termina en un golpe de efecto para alcanzar un final «casi feliz» (y característico de Alonso de Santos). Establece así el autor una suerte de parábola acerca de la situación de la posguerra y la dramatiza.

En este sentido, la referencia histórica implícita es la misma que en Sanchis Sinisterra: una sociedad que se pretende nueva, pero que se funda sobre la violencia y que remite a la ruptura social y al enfrentamiento como legitimación de sí misma. En un momento, María, ayudante de cocina, comenta: «¿Por qué nos tienen ese odio? Ya han ganado la guerra...» (Alonso, 2008: 858). Verdaderamente no hace falta más. Por otra parte, ambos autores eligen también una perspectiva que se centra en situaciones cotidianas, con personajes anónimos, más atentos a la verdad de lo verosímil que a la exactitud de los hechos. Aunque en esto hay una gran diferencia entre uno y otro. Finalmente, tratan con particular atención a los vencidos, por deber del presente. Las expectativas anteriores a la sublevación y el resultado de la guerra civil ofrecen un contraste doloroso para estos jóvenes prisioneros (y más claramente para la pareja que no pudo casarse antes de ser detenidos). Aparece aquí el tema de las promesas incumplidas del pasado, que se ha convertido para ellos en un presente de represión y en memoria dolorosa. Y el final que propone Alonso de Santos trata precisamente de hacer que esas promesas puedan verse cumplidas en la ficción, como rectificación simbólica y moral de la realidad histórica (los novios se casan e incluso podrán escapar).

Más allá de estas semejanzas de fondo, propias de la época, se imponen las diferencias de talante personal y literario. Por ello, la comparación entre las dos obras ofrece contrastes y puntos de vista complementarios para abordar este tema de las memorias dramáticas del franquismo. La diferencia esencial es la que ya he anticipado. Sanchis Sinisterra opta por una ficción veredictiva, que resume en un caso ejemplar los de muchos (comprobables), con sus circunstancias, según categorías y tipos: la mujer viuda sin serlo, la viuda de guerra con un hijo, el profesor depurado, el exiliado, el clandestino, el escondido, etc. Alonso de Santos, en cambio, se decanta por una historia imaginaria que impone desde el comienzo su condición ficcional, con sucintas pero inevitablemente ominosas referencias a la realidad exterior. A partir de ahí, el tratamiento dramático de cada uno se sitúa en un extremo opuesto del otro. Terror y miseria... se frag- 
menta en escenas independientes, breves, que dan al espectador un conjunto de situaciones que responden, de forma directa e inmediata, a la realidad de la España vencida, sobre todo. Mientras que La cena de los generales desarrolla la acción básica mediante una trama argumental, con doble nivel, disolviendo de alguna manera la inmediatez testimonial.

Al observar las características de los personajes y del lenguaje dramático, se percibe bien la diferencia entre una perspectiva (de Sanchis Sinisterra) que llamaremos «fría», que recurre al patetismo duro y cuyo humor queda helado en una atmósfera opresiva e intransigente, y otra perspectiva más «cálida» (de Alonso de Santos), que busca en todo momento situaciones de aproximación humana personal, que contiene buenas dosis de sentimentalidad y humor, aunque tampoco renuncia a insertar momentos de violencia directa, en contraste con otros de relativa y abierta comicidad, ni a conmover con los mismos recursos. Cuando comienza la obra encontramos la siguiente acotación: «Todo tiene un aspecto tristón y mortecino, como la rota España de aquel momento» (Alonso, 2008: 806). Luego entran las dos mujeres: «vestidas con ropas de presa y las cabezas rapadas [...] Tienen una pinta patética, y los cocineros se quedan muy conmovidos al verlas así» (Alonso, 2008: 819).

Estas dos maneras dramáticas de abordar la misma situación histórica y los mismos hechos, referidos en la memoria colectiva, apuntan hacia dos modos de relacionar el presente con las imágenes del pasado (pues aquí el teatro tiene ese poder de presentar la imagen misma de la memoria), siempre en busca de dar sentido a la experiencia y a la posibilidad de la convivencia social. Sanchis Sinisterra muestra el pasado en su agria realidad, lo atrae sobre el presente con su calidad testimonial para que no se olvide o se diluya entre las tendencias negadoras o restauracionistas y nostálgicas. El recuerdo sirve para advertir y corregir. No se trata de memorias diferentes u opuestas (de los vencedores o de los vencidos), sino del esfuerzo y, otra vez, del trabajo de la memoria, pues el olvido es siempre la amenaza latente, frente a la absolución interesada del pasado. Por el contrario, Alonso de Santos aleja el pasado, lo refiere al origen que no hay que olvidar, pero que requiere ser comprendido. ${ }^{7} \mathrm{Y}$ por ello no basta reconocer el testimonio social, sino atender a los comportamientos individuales. La obra termina con una realización de «justicia poética» (castigo de la persona más sectaria) y con un gesto de nobleza, que permite ese desenlace que apunta hacia

7. Ni esta comprensión ni el planteamiento humanamente «cálido» de la obra permiten ser interpretados como una actitud de justificación indiscriminada o una coartada encubridora de los hechos en el propósito dramático del autor. Queda clara su simpatía, aunque también su idea de la necesidad y posibilidad de las relaciones por encima de las fracturas ideológicas. Digamos que introduce un elemento de salvación.

Anales, 21, 2009, pp. 11-38 
la felicidad por medio de la libertad. El pasado/pasado ha sido y ya no parece repetible. Es distinto del presente (aunque esté en su origen) y por ello desde el presente hay que tratar de conocerlo: «he intentado [...] tender un puente que dé valor hoy a los conflictos y enfrentamientos de esos días ante los ojos del espectador actual» (Alonso, 2008: 803). Los supone alejados y, por tanto, tiene que tender un puente para relacionarlos con el espectador. Esta visión vendrá acompañada de humor y de comprensión, puesto que no es ajena, pero tampoco llega a resultar presente. Así habría que leer esta otra afirmación del autor en su Nota: «La comedia, su tono y su lenguaje, será el estilo unificador que aglutine los conflictos dramáticos -e históricos- con la dimensión temporal de la obra. Miramos atrás sin ira, con la piedad humana que da la distancia y el arte» (Alonso, 2008: 803).

De esta manera, el conflicto dramático recrea en otra clave -la de la comedia- el conflicto histórico. De ahí su valor de memoria. Se trata de una muestra de la posible mirada indulgente, no sobre los hechos violentos o la crueldad institucionalizada, sino sobre la desnuda vida humana que, en esas circunstancias, aún trata de realizar unos valores (sin énfasis) y que, a través del dolor y del riesgo, llega a superar su propia situación de miseria. Alonso de Santos no propone igualdad o simetría en las conductas de un grupo y otro. Tampoco me parece que se trate de olvido y perdón, menos aún de reconciliación o amnistía (sigue sin buscar el énfasis en el tratamiento de la historia), sino más bien, según sus palabras, de ver desde la propia distancia, que es la nuestra, y a través de una comprensión cargada de emoción, lo más triste de nuestro pasado.

Ante esta dualidad de planteamientos, se puede pensar que tal vez los dos, el «horror»y el «humor», son necesarios y útiles para un presente sano, capaz de recuperar e integrar estas memorias selectivas de un pasado inmediato, y de encontrarle sentido desde un cierto proyecto común. Porque la otra alternativa es el silencio y el olvido que transforma ese pasado en un espacio vacío y transparente.

Y a esto me refiero con el comentario de las dos obras siguientes, que plantean el asunto en términos de debate. Son ejemplos paradigmáticos y contrapuestos de la necesidad de la memoria como recuperación del pasado y actualización permanente del legado histórico. No basta que el presente sea consecuencia de determinados hechos, para que eso se muestre con plenitud y con sentido, es necesario que se mantengan en la memoria colectiva y adquieran su valor concreto en el punto y momento desde el que se mira.

Por una parte, tenemos la necesidad de la memoria para el vencedor, de manera que el recuerdo de su victoria le mantenga siempre en el lugar único (Caudillo), referido al hecho fundacional de su poder y de su sistema. De algún 
modo regresamos al inicio de estas páginas, pero evidentemente con otra perspectiva temporal, pues la obra que refiere así la cuestión está escrita en 1976, por lo que se propone, de esta manera, como una suerte de memoria crítica y en debate. Por otra parte, hay una memoria de los vencidos o de los represaliados durante el franquismo que ha parecido borrarse, de acuerdo a cierta perspectiva ideológica y aun estética, y a una urgencia o necesidad o comodidad política de supuesta reconciliación. ¿Puede esto último eliminar o prescindir de lo primero? ¿Sobre qué se funda ese mismo acuerdo, ese edificio de nuevo uso de la democracia? También esta memoria debe ser mantenida. Este es el motivo del debate de la segunda obra.

Última batalla en el Pardo, de Rodríguez Méndez, plantea una situación dramática con algunos aspectos originales: su referencia única es la guerra civil, y su personaje principal es el mismo Franco (que, en la inmediatez de su muerte, debió interesar al dramaturgo, que trató de desvelar su enigma). No se trata ya de recordar solamente o de analizar los hechos, sino de reproducir, con otros medios y recreando las circunstancias, la victoria y sus causas. Es lo que pretende Franco al invitar a un general vencido a encontrarse con él en un ficticio campo de batalla, pues lo que ocurrió no puede ser cambiado, sino solamente repetido. Y ésta es su memoria: volver sobre el hecho fundacional de su poder y de su régimen como resultado sólo de su actuación personal. Para satisfacer esta necesidad quiere renovar permanentemente su referencia mediante una suerte de ritual castrense, de celebración íntima en que los papeles están asignados y son inmutables. Tanto el escenario como el personaje se presentan adecuadamente configurados para esta función, iconizados, si puede decirse: la escena crea el espacio sagrado del refugio de trinchera, aislado, «islote de resistencia» en el Palacio de El Pardo, frente al exterior y al devenir del tiempo, y dentro de él, la figura de Franco, no en su condición de gobernante, sino de general, vestido de campaña.

La estrategia de la intriga parece conducida por la imposición del vencedor sobre el vencido. Del primero es la iniciativa de los encuentros, pues necesita recordar una y otra vez; y en esos encuentros se repite la actitud de ataque de uno y de defensa del otro, siempre con el mismo final, pues, tal como dice Franco, el espíritu defensivo aboca a la rendición. Aunque en verdad apenas puede haber defensa del otro, cuando en el drama Franco es un personaje bien definido en sus gestos, indumentaria, nombre y pasado, mientras «el general vencido» carece de nombre, apenas de historia y aparece con un rostro impreciso y un indumentaria civil. Además, ese espacio, cerrado y de combate, corresponde a la conciencia de Franco, donde éste se siente identificado como lo que es: «Aquí, en estos amorosos recuerdos, es donde me vuelvo a reencontrar a mí mismo» 
(Rodríguez Méndez, 2005: 416). Por otra parte, el proceso del tiempo en que se realizan los encuentros desgasta más al vencido que al vencedor. Parece que esa derrota, repetida y siempre renovada, contribuye a minar su salud y le conduce a la muerte, que el vencedor interpreta también como su última victoria.

En relación con el planteamiento histórico de la acción, se advierte un especial cuidado en la revisión de los hechos militares, aunque sin ocupar todo el centro de interés. Dos son los aspectos más significativos, según los enuncia el personaje principal. Primero, que el presente no es más que la consecuencia y administración de la victoria: «La actualidad no es ni más ni menos que la consecuencia lógica de nuestra cruzada» (Rodríguez Méndez, 2005: 430). El pueblo parece haberlo aceptado así y, en cierta forma, también olvidado, por eso el general vencedor requiere al vencido, pues que, decía Ricoeur, uno no recuerda solo, sino con ayuda de los recuerdos del otro. Y éste es el papel del vencido. Hay así una estrecha relación entre victoria y memoria: ésta es necesaria para mantener viva a aquélla; y en medio, entre ambas, su aprovechamiento político. Y segundo aspecto, que la victoria fue necesaria por muchos motivos, entre los cuales enumera la desunión del enemigo, la falta de profesionalidad, no aprovechar un ideal común, el espíritu meramente defensivo; y además, por su lado, la convicción de la victoria, la estrategia y el planeamiento estrictos, la unión firme, el motor de la religión, etc. Debido a este planteamiento militar, en la obra se habla de procesos, planes, fuerzas y estrategias, pero escasamente de valores. Y cuando algo de esto se dice, nunca lo hace el general vencido, porque para el vencedor el único valor esencial es él mismo. ${ }^{8}$

Tal vez en este punto encontramos el sentido principal de esta obra, que se niega a la simplificación y no muestra interés por las justificaciones ideológicas o políticas. Se trata aquí del fatalismo de la victoria de Franco y de su consolidación (ya que la perspectiva dominante es la suya, como he dicho): «Ustedes perdieron porque no querían ganar», lo que significa que no hay un determinismo ajeno a los determinantes históricos y humanos, y esto es claro para Franco: «yo siempre supe que ganaría [...] La fatalidad soy yo» (Rodríguez Méndez, 2005: 428). Y aquí hay que anotar que no se puede confundir la figura real e histórica con su duplicación como personaje dramático. El que habla así es el Franco ficticio, y a través de sus palabras nos parece acceder al significado histórico de este debate que ha forjado Rodríguez Méndez. No es la justificación del resultado de la guerra y de sus consecuencias, menos aún de su comienzo, sino la explicación del

8. La legitimidad democrática, la fidelidad al orden constitucional y una cierta supremacía moral fueron constantes referencias de los exiliados en sus memorias de la derrota. Esta dimensión moral no aparece con claridad en el general vencido. ¿Un signo más de su derrota o una omisión del autor?

Anales, 21, 2009, pp. 11-38 
proceso. Dicho de otro modo, la obra trata de la imposición del punto de vista del vencedor como único posible durante un largo tiempo y la fijación necesaria de su propia memoria, utilizando como mediación al adversario. ${ }^{9}$

De ahí el planteamiento dramático en escenas independientes que son encuentros en que la reproducción de la historia se realiza como un simulacro de combate entre dos memorias asimétricas, por las que se va filtrando el sentido. Esta reproducción ficticia y simbólica de la guerra muestra que, para el vencedor, los hechos se han convertido en un derecho, no sólo de conquista, sino de destino: debían ganar la guerra porque actuaron como vencedores. Y a partir de aquí se establece el principio de permanencia: «Espero morir en paz, en el poder... y perpetuada mi memoria» (Rodríguez Méndez, 2005: 440).

Ya que la rememoración no puede ir más que en un sentido, pues lo acontecido no se cambia, parece echarse de menos un tercer elemento, una conciencia crítica ajena al debate. Si no, parecería que la historia tuviera que repetirse y que el vencedor nunca dejaría de serlo. Aquí es preciso, entonces, apelar al juicio moral del espectador, esperar una reacción ante este supuesto de la necesidad histórica y de su memoria. Al fin, cuando el drama se escribió, las consecuencias de esa situación estaban todavía vigentes en todas sus formas institucionales y eran estrictamente más parte del presente que de la memoria. Entonces y después suscita, sin duda, una serie de interrogantes que su acción verbal y dialéctica no cancela ni decide.

En El arquitecto y el relojero (2000), López Mozo sigue fiel a la idea ya presentada en su obra sobre el exilio, antes comentada. La nueva obra reduce a dos la nómina de personajes dialogantes, con ayuda ocasional del utilero y los tramoyistas. Se plantea dramáticamente, pues, desde una dicotomía en aspectos estructurales, dentro de la cual se inserta el debate sobre una parte de las marcas de la memoria colectiva y su presencia o eliminación. El punto de partida es histórico, ya que se refiere a una reforma del edificio más conocido de la Puerta del Sol, de Madrid, para adecuarlo al nuevo destino (1996-1998). Así, lo que se estableció en el siglo XVIII como Real Casa de Correos, pasó luego a Ministerio de Gobernación, a Dirección General de Seguridad en el franquismo y a sede de la Presidencia de la Comunidad de Madrid.

Tal como comienza el drama, con proyecciones de grabados y fotografías del edificio desde su construcción, aparece la memoria antes que los recuerdos, paradójicamente, ya que éstos pueden crearse a partir de las imágenes. Pero el

9. Decía antes que en estas obras la alternativa a la memoria era el olvido; así hay que entenderlo aquí, como el silencio del general vencido, pues, al terminar la lectura, difícilmente recordamos más que su situación subordinada y vacilante.

Anales, 21, 2009, pp. 11-38 
edificio sostiene uno de los relojes más famosos de España. Así se establece un ámbito teatral de la representación (espacio sobre la fábrica y al pie del reloj) con valor simbólico: el mismo edificio, estable, permanente y cuyo proceso hemos contemplado, es referencia histórica, aunque degradada por su largo y poco respetuoso empleo, edificio enfermo, como la misma sociedad a la que ha servido; y el reloj es el tiempo, a la vez sucesivo e inalterable, permanencia que rige el tiempo humano como tiempo histórico, pero que requiere también cuidado y conservación particularmente delicados. Y ahí está el Relojero, para mantener y cuidar, como está el Arquitecto para restaurar, sanar, renovar, «con audacia y nuevas ideas», el edificio. La edad de cada uno no parece insignificante: el Relojero puede haber nacido (como el autor) a comienzos de los años cuarenta. Y el Arquitecto, a comienzos o mediados de los sesenta.

Pronto aparecen las dos actitudes opuestas. El Arquitecto planea una reforma radical en estos términos: «Mi obra será una muestra de luz y transparencia que eliminará los rincones más oscuros de este edificio. Tras esta fachada que certifica su edad, surgirá un espacio sin barreras [...] Un espacio inocente y virgen. Un espacio en blanco, como las páginas de un cuaderno sin estrenar, puesto a disposición del hombre actual para que escriba su historia» (López Mozo, 2001: 34). El peligro que salta a la vista del Relojero es que con esto se arrase lo que es también parte de la historia (y de la edad del edificio, por tanto) y que no se muestra hacia fuera (fachada), no en el rostro sino en sus vísceras. Pues todo es edificio o sociedad. «Aquí han ocurrido cosas que no debemos olvidar» (López Mozo, 2001:37). Y el verbo empleado es significativo, porque está apelando directamente al deber de la memoria, como registro ético de la sociedad. El Arquitecto mantiene que «nada que merezca ser salvado, desaparecerá». Se refiere a lo antiguo, aquello que ya no importa vitalmente ahora y encierra una imagen colectiva positiva y gloriosa, como la sublevación del 2 de mayo. Pero no la proclamación de la República y menos aún las prácticas de tortura y los sótanos de los calabozos del franquismo. Recordar lo reciente es para él inoportuno. Y parece que no sólo por reciente.

El fundamento de esta posición (en que se trata de sintetizar una línea política de la transición) se reduce tal vez a tres series de enunciados básicos de los motivos: motivos estéticos de preferencia minimalista, una pureza posmoderna que alberga una ideología; motivos políticos que se resumen en la prudencia con que conviene gobernar (no molestar, parece); motivos prácticos: es más importante administrar que recordar. Pero hay incluso una filosofía, la del humanismo abstracto y el adanismo histórico: «A nadie me debo, más que al hombre [...] pretendo crear un espacio a la medida del nuevo ciudadano» (López Mozo, 2001: 62), el «cuaderno en blanco».

Anales, 21, 2009, pp. 11-38 
Naturalmente se mantiene la apariencia de la historia (la fábrica con su fachada), mientras de ella se extirpa la parte viva que es la memoria. Y al borrar esa memoria del tiempo (que preside el reloj) se cambia su identidad, que resulta ser también la pretensión: «por dentro será otra». Se ve que, al hilo del debate, brotan los problemas esenciales: el cambio y la permanencia en relación con la identidad social y colectiva, la orientación de una sociedad en el tiempo (de dónde viene, hacia dónde va), la relación con el pasado inmediato, especialmente con el negativo o traumático, la necesidad de los recuerdos apoyados en huellas o testimonios, etc.

Frente a esta posición de autosuficiencia, el Relojero acusa al Arquitecto de borrar las huellas y, por lo tanto, de impedir que se pueda hacer justicia a las víctimas de los «tiempos de silencio» (López Mozo, 2001: 37-38). Advierte de que, con la reforma, quedará «un edificio sin memoria» (45), porque, al pasar dos o tres generaciones, «ejercitándose en el olvido voluntario», sobrevendrá fatalmente la amnesia. Y por todo ello añade:

El hombre sin recuerdos se convierte en un ser estúpido.

En un cadáver.

Sólo vive el que recuerda [...]

Reivindico un espacio mínimo,

un espacio al que se acceda traspasando la puerta de una celda [... ]

un lugar semejante a los que existían aquí,

abajo, en los sótanos...

(López Mozo, 2001: 46-47)

A continuación, evoca la función de ese edificio en la represión política y como lugar de tortura para muchos detenidos (algunos arrojados por las ventanas): «cadáveres de españoles, en definitiva» (López Mozo, 2001: 52). En este punto del debate la escena recrea, mediante proyecciones, algunas prácticas de esas sesiones de interrogatorio, de modo que la memoria negada (por la obra del Arquitecto) siga siendo imagen viva para el espectador de la obra. Y repite la pregunta al final: «Qué fue de ellos, qué fue de ellos...» (López Mozo, 2001: 64). El Arquitecto responde con los motivos que ya he resumido: razones estéticas y políticas desaconsejan mantener o instalar una réplica de ese habitáculo. Se guardarán las cosas para otra ocasión.

El edificio renovado se inaugura con una nueva cúpula, una transparencia de la luz que no ilumina nada, o, si acaso, a los propios personajes que ahora lo ocupan. Entonces el Relojero arroja la enorme bola de la maquinaria y los documentos y materiales rescatados y escondidos por él, para terminar lanzándose él mismo a ese vacío de aire y luz que ha creado la cúpula de cristal. Si seguimos con el desarrollo del símbolo, se puede decir que el personaje, testigo y conciencia del tiempo, se lanza por el vacío actual de la cúpula para romper 
ese teatro de la luz y la nada, que sustituye y oculta el teatro de las sombras y el silencio.

Algunas consecuencias parecen deducirse de este debate (no maniqueo, pero en absoluto neutral). La primera, que no se trata en ningún momento de un juicio (penal, político ni siquiera social), sino del reconocimiento necesario de la realidad oculta en la oscuridad. Porque no se pueden eliminar impunemente las sombras de la historia. La segunda, que en la nueva sociedad (porque tiene que ser nueva) ha de estar presente de algún modo el recuerdo de las víctimas, por razón de justicia. La tercera, que se trata de no olvidar, lo que no es igual a recordar. Ambas fórmulas (a pesar de su semejanza) se diferencian en matices importantes de la relación entre el pasado y el presente. Recordar puede ser volver hacia atrás, rescatar con la conciencia un pasado ya extinguido en su valor o responsabilidad. No olvidar es seguir llevando el peso de ese pasado como exigencia ética actual. Y esto es una necesidad para que ese pasado confiera peso, densidad y conocimiento plenamente humanos a la construcción del presente colectivo.

No hay desenlace porque no hay solución ni síntesis satisfactoria en el debate. Todo parece que vuelve a empezar, como si lo visto en la representación fuera un sueño premonitorio que va a cumplirse de inmediato, o una parte de un proceso inacabable. La dicotomía, con que se ha planteado la obra al inicio, se transforma así en la dialéctica misma de la historia entre novedad y permanencia, técnica y maestría, estética y ética, negación y rememoración, olvido y recuerdo, pasado y presente, en fin.

Esta propuesta de revisión se ha fijado necesariamente sólo en algunas obras y aun en parte de las muchas posibilidades que éstas ofrecían. Queda pendiente estudiar, en relación con la memoria, otros aspectos de la teatralidad y también las formas y estrategias dramáticas con que la memoria puede ser evocada y recuperada, dentro del horizonte de expectativas de los diferentes grupos de espectadores actuales. El recorrido, como dije al comienzo, se ha centrado en el hecho mismo de la memoria, en relación con su necesidad y de su dificultad. Pero, al menos y en conclusión, con lo mostrado puede quedar constancia de que el teatro español ha sido también testigo de los conflictos de la memoria, los ha integrado como parte de su representación, e incluso, con censura y sin ella, desde la inmediatez, la lejanía o la ausencia, ha creado su propia memoria. 


\section{BIBLIOGRAFÍA}

AA.VV. (1999), Teatro Histórico (1975-1998). Textos y representaciones (José Romera Castillo y Francisco Gutiérrez Carbajo, eds.), Madrid, Visor.

ALONSO DE SANTOS, José Luis (2008), Obra Teatral, 2, Madrid, Castalia.

AUB, Max (1968), Teatro Completo, México, Aguilar.

BUERO VALLEJO, Antonio (1994), Obra Completa. I, Teatro (ed. de Luis Iglesias

Feijoo y Mariano de Paco), Madrid, Espasa-Calpe, 1994.

JAISSON, Marie (2008), «La topografía legendaria y la investigación sobre la memoria colectiva en Maurice Halbwachs», Anthropos, 218, pp. 96-109.

LÓPEZ MOZO, Jerónimo (2001), El Arquitecto y el Relojero, Alicante, Ayto. de Alicante.

- (2003), El olvido está lleno de memoria. Ade Teatro, 98, pp. 160-178.

RICOEUR, Paul (1998), La lectura del tiempo pasado: memoria y olvido, Madrid, Arrecife/UAM.

- (1999), Historia y narratividad, Barcelona, Paidos/UAB.

RODRÍGUEZ MÉNDEZ, José M. ${ }^{a}$ (2002), «Mi generación realista», en Salvador Montesa (ed.), Teatro y antiteatro. La vanguardia del drama experimental, Málaga, Publicaciones del Congreso de Literatura Española Contemporánea.

- (2005), Teatro escogido, II, Madrid, AAT.

SANCHIS SINISTERRA, José (1998) Naque, jAy, Carmela! (ed. de Manuel Aznar Soler), Madrid, Cátedra.

- (2003), Terror y miseria en el primer franquismo (ed. de Milagros Sánchez Arnosi), Madrid, Cátedra.

TAIBO, Paco Ignacio (1983), Morir del todo, Primer Acto, 201, pp. 52-77.

Fecha de recepción: 1 de mayo de 2008

Fecha de aprobación: 15 de octubre de 2008 